\title{
Seasonal and temporal changes in nitrous oxide emission with fertilizer application in rice ecosystem of North Bank Plain Agroclimatic Zone of North East India
}

\author{
Boby Gogoi ${ }^{1, *}$, Kushal Kumar Baruah ${ }^{2}$ \\ ${ }^{1}$ Department of Plant Physiology \& Breeding, TTRI, TRA, Jorhat-785008, Assam, India \\ ${ }^{2}$ Department of Environmental Science, Tezpur University, Tezpur-784028, Assam, India
}

Email address:

mgkhat@yahoo.co.in (B. Gogoi), kushal_baruah@rediffmail.com (K. K. Baruah)

\section{To cite this article:}

Boby Gogoi, Kushal Kumar Baruah. Seasonal and Temporal Changes in Nitrous Oxide Emission with Fertilizer Application in Rice Ecosystem of North Bank Plain Agroclimatic Zone of North East India. International Journal of Environmental Monitoring and Analysis. Vol. 2, No. 5, 2014, pp. 289-296. doi: 10.11648/j.ijema.20140205.19

\begin{abstract}
Fertilizer dosage can influence nitrous oxide $\left(\mathrm{N}_{2} \mathrm{O}\right)$ emissions in rice (Oryza sativa L.) fields. An experiment was conducted to find out the temporal and seasonal variations in $\mathrm{N}_{2} \mathrm{O}$ emissions under different doses of fertilizers and to identify the best fertilizer combination for lower $\mathrm{N}_{2} \mathrm{O}$ emission and adequate yield potential. Two rice varieties Phorma (local cultivar) and Luit (high yielding variety) were grown, with nine different fertilizer treatments. $\mathrm{N}_{2} \mathrm{O}$ fluxes were measured by a closed chamber technique. Temporal fluxes coincide with fertilizer application. Higher seasonal $\mathrm{N}_{2} \mathrm{O}$ emission $\left(\mathrm{E}_{\mathrm{sif}}\right)$ of $224.05 \mathrm{mg}$ $\mathrm{N}_{2} \mathrm{O}-\mathrm{N} / \mathrm{m}^{2}$ (in Phorma) and $182.16 \mathrm{mg} \mathrm{N} \mathrm{N}_{2} \mathrm{O}-\mathrm{N} / \mathrm{m}^{2}$ (in Luit) was observed in treatment $\mathrm{T}_{9}\left(45: 22: 22 \mathrm{~N}_{-} \mathrm{P}_{2} \mathrm{O}_{5}-\mathrm{K}_{2} \mathrm{O} \mathrm{kg} / \mathrm{ha}\right.$ as urea, single super phosphate and muriate of potash + farm yard manure). Whereas, lowest emission was recorded in $\mathrm{T}_{2}(35: 18: 18 \mathrm{~N}-$ $\mathrm{P}_{2} \mathrm{O}_{5}-\mathrm{K}_{2} \mathrm{O} \mathrm{kg} / \mathrm{ha}$ as urea, single super phosphate and muriate of potash). $\mathrm{N}_{2} \mathrm{O}$ emission also showed significant positive correlations with soil nitrate- $\mathrm{N}$ and soil organic carbon. The fertilizer dose $\mathrm{N}, \mathrm{P}_{2} \mathrm{O}_{5}, \mathrm{~K}_{2} \mathrm{O} @$ @ 40:20:20 kg/ha as urea, single super phosphate and muriate of potash $\left(\mathrm{T}_{1}\right)$ without farm yard manure was found to be suitable for sustaining productivity and lower $\mathrm{N}_{2} \mathrm{O}$ emission in this zone.
\end{abstract}

Keywords: Fertilizer Dose, Farm Yard Manure, $\mathrm{N}_{2} \mathrm{O}$ Emission, Grain Yield, Rice

\section{Introduction}

The main greenhouse gases that contribute to global warming and climate change are water vapor, carbon dioxide $\left(\mathrm{CO}_{2}\right)$, methane $\left(\mathrm{CH}_{4}\right)$, nitrous oxide $\left(\mathrm{N}_{2} \mathrm{O}\right)$ and ozone $\left(\mathrm{O}_{3}\right)$. Since the industrial revolution, the concentration of $\mathrm{N}_{2} \mathrm{O}$ in the atmosphere has increased from around $270 \pm 7 \mathrm{ppb}$ in 1750 , to $319 \pm 0.12 \mathrm{ppb}$ in 2005 [1]. Fertilizers or manures applied to agricultural soils are direct sources of $\mathrm{N}_{2} \mathrm{O}$ and atmospheric nitrogen depositions, sewage and loss of nitrogen from agricultural fields through leaching and runoff are indirect sources. Several studies have indicated that $\mathrm{N}_{2} \mathrm{O}$ emissions are influenced by the rate and type of fertilizers applied [2], [3]. Higher nitrogen and phosphorous fertilizer doses were found to emit higher $\mathrm{N}_{2} \mathrm{O}$ fluxes from the interaction of $\mathrm{N}$ and $\mathrm{P}$ fertilizers under an irrigated rice system [4]. $\mathrm{N}_{2} \mathrm{O}$ emissions double to $10 \mathrm{~kg} \mathrm{~N} \mathrm{~N}_{2} \mathrm{O}-\mathrm{N} / \mathrm{ha} /$ year when $\mathrm{N}$ applied at $400 \mathrm{~kg} \mathrm{~N} / \mathrm{ha} /$ year [5]. Recent investigations have showed that when annual fertilizer rates increased from 270 to 430 , from 270 to 650 , and from 270 to $850 \mathrm{~kg}$ $\mathrm{N} /$ ha/year, cumulative $\mathrm{N}_{2} \mathrm{O}$ emissions increased from 35$115 \%$ [6]. With increasing $\mathrm{N}$ application rates total $\mathrm{N}_{2} \mathrm{O}$ emission during the wheat growing period increased linearly from 32 to $164 \%$ [7]. Significant increase in cumulative $\mathrm{N}_{2} \mathrm{O}$ emissions with increasing $\mathrm{N}$ application rates were reported during potato and corn growing season [8], [9]. Although few studies on effect of fertilizer rates on $\mathrm{N}_{2} \mathrm{O}$ emission from different cropping systems in India are reported but no such studies were conducted in North Bank Plain Agroclimatic Zone of Assam of India where rice is the major cereal crop grown throughout the year under different ecosystem. Therefore, present study was conducted with an objective to find out the temporal and seasonal variations in $\mathrm{N}_{2} \mathrm{O}$ emissions from rice field under different doses of fertilizer treatments and to identify the best fertilizer combination for lower $\mathrm{N}_{2} \mathrm{O}$ emission and adequate yield potential in rice ecosystem of North Bank Plain Agroclimatic Zone of Assam. 


\section{Study Area}

The study was conducted in North Bank Plain Agroclimatic Zone (NBPAZ) of Assam at Tezpur, India (Figure 1). The experimental area is located at $26^{\circ} 41^{\prime} \mathrm{N}$ latitude and $92^{\circ} 50^{\prime} \mathrm{E}$ longitude in a farmer's field at about 6 $\mathrm{km}$ distance from Tezpur Central University, Assam. The average weekly precipitation and maximum and minimum average air temperature recorded during the experimental period are shown in Figure 2. This zone is characterized by light textured loamy alluvial soils. Prior to inception of treatments experimental site soils contained $29.02 \%$ sand, $40.69 \%$ silt, $30.29 \%$ clay, $377 \mathrm{~kg} / \mathrm{ha}$ available nitrogen, 35 $\mathrm{kg} / \mathrm{ha}$ available phosphorus and $240 \mathrm{~kg} / \mathrm{ha}$ available potassium, $0.91 \%$ organic carbon, soil $\mathrm{pH} 5.2$.

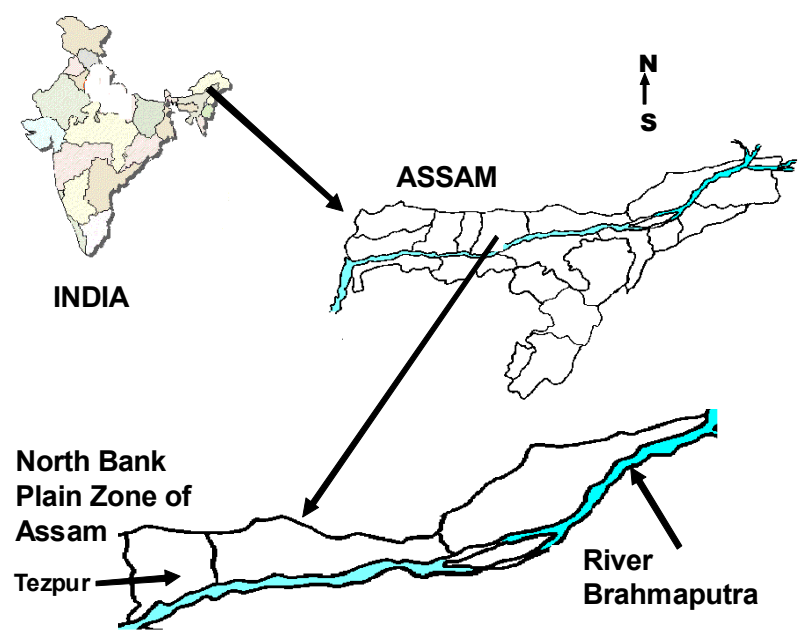

Figure 1. Experimental site at North Bank Plain Agroclimatic Zone

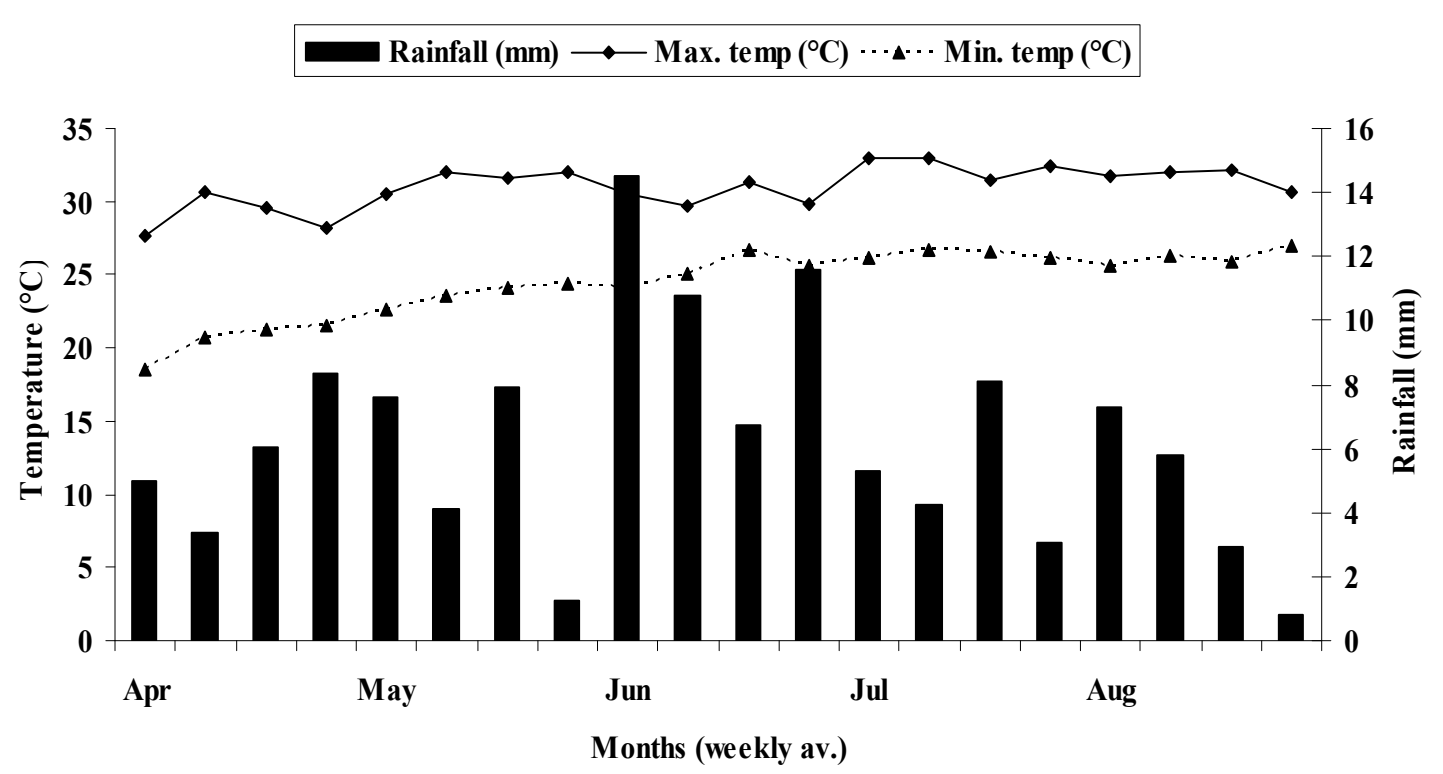

Figure 2. Meteorological parameters during the experimental period

\section{Methods}

Two popularly grown rice varieties namely Phorma and Luit were selected for this experiment. Luit is a high yielding, semi-dwarf, white kernelled photoperiod insensitive variety. Phorma is an indigenous traditional rice cultivar. Plants are of medium height with strong culm and good tillering ability. The seedlings of these varieties were transplanted in well prepared plots (area $=2 \mathrm{~m} \times 2 \mathrm{~m}$ ) comprising of nine different fertilizer treatment combinations, each replicated three times in randomized block design on May, 17, 2008. The form and doses of fertilizer treatments are $\mathrm{T}_{1}: \mathrm{N}, \mathrm{P}_{2} \mathrm{O}_{5}$, $\mathrm{K}_{2} \mathrm{O} @$ @0: 20: $20 \mathrm{~kg} / \mathrm{ha}$ as Urea, SSP (Single Super Phosphate) and MOP (Muriate of Potash), $\mathrm{T}_{2}: \mathrm{N}, \mathrm{P}_{2} \mathrm{O}_{5}, \mathrm{~K}_{2} \mathrm{O}$ (a) 35:18:18 kg /ha as Urea, SSP, MOP, T $:$ N, $\mathrm{P}_{2} \mathrm{O}_{5}, \mathrm{~K}_{2} \mathrm{O}$ @ 45:22:22 kg/ha as Urea, SSP, MOP, T $\mathrm{T}_{4}: \mathrm{N}, \mathrm{P}_{2} \mathrm{O}_{5}, \mathrm{~K}_{2} \mathrm{O}$ @ 40:20:20 kg/ha as Urea, DAP (Diammonium Phosphate), 
MOP, $\mathrm{T}_{5}: \mathrm{N}, \mathrm{P}_{2} \mathrm{O}_{5}, \mathrm{~K}_{2} \mathrm{O} @ 35: 18: 18 \mathrm{~kg} / \mathrm{ha}$ as Urea, DAP, MOP, $\mathrm{T}_{6}: \mathrm{N}, \mathrm{P}_{2} \mathrm{O}_{5}, \mathrm{~K}_{2} \mathrm{O} @$ 45:22:22 kg/ha as Urea, DAP, MOP, $\mathrm{T}_{7}: \mathrm{N}, \mathrm{P}_{2} \mathrm{O}_{5}, \mathrm{~K}_{2} \mathrm{O} @$ 40:20:20 kg/ha as Urea, SSP, $\mathrm{MOP}+$ farm yard manure (FYM), $\mathrm{T}_{8}: \mathrm{N}, \mathrm{P}_{2} \mathrm{O}_{5}, \mathrm{~K}_{2} \mathrm{O}$ @ 35:18:18 kg/ha as Urea, SSP, MOP + FYM, T 9 : N, $\mathrm{P}_{2} \mathrm{O}_{5}, \mathrm{~K}_{2} \mathrm{O}$ (a) 45:22:22 kg/ha as Urea, SSP, MOP + FYM. One third of total dose of $\mathrm{N}$ was applied at the time of final puddling before transplanting along with full dose of $\mathrm{P}_{2} \mathrm{O}_{5}$ and $\mathrm{K}_{2} \mathrm{O}$. The second and third doses of $\mathrm{N}$ were applied at tillering and panicle initiation stages, i.e. at 30 and 47 days after transplanting (DAT) of the crop. FYM was applied in treatments $\mathrm{T}_{7}, \mathrm{~T}_{8}$ and $\mathrm{T}_{9} @ 10 \mathrm{t} / \mathrm{ha}$ along with other fertilizers at the time of final land preparation. Crop was harvested on 4 th August, 2008. Gas samples were collected by a closed chamber technique. The collected gas samples analyzed for $\mathrm{N}_{2} \mathrm{O}$ fluxes, using a Varian model 3800 gas chromatograph (USA) fitted with an electron capture detector (ECD). $\mathrm{N}_{2} \mathrm{O}$ flux was calculated as described earlier [10]. Cumulative $\mathrm{N}_{2} \mathrm{O}$ emission for the entire crop growth period was computed by the method given by [11]. Cumulative $\mathrm{N}_{2} \mathrm{O}$ emission is expressed as seasonal integrated flux $\left(\mathrm{E}_{\text {sif }}\right)$ in $\mathrm{mg}$
$\mathrm{N}_{2} \mathrm{O}-\mathrm{N} / \mathrm{m}^{2}$. Soil samples were randomly collected from each plot from a depth of $15 \mathrm{~cm}$ using a core sampler. Soil nitrogen content was determined by Kjeldahl's method [12]. Phosphorus and potassium content in soil were determined by Bray's I method and Flame photometric method, respectively [13]. Soil $\mathrm{pH}$ was measured at 1:2.5 soils to water ratio using a digital $\mathrm{pH}$ meter (Systronics Griph model $\mathrm{D}$ pH meter). Organic carbon of the soil at weekly interval was estimated by wet digestion method [14]. Soil nitrate nitrogen content was determined on each $\mathrm{N}_{2} \mathrm{O}$ flux measurement day at weekly interval by Phenol disulphonic acid method [15]. Rice yield was determined from the total plot area by harvesting all the hills excluding the hills bordering the plots.

The statistical package SPSS version 11.5 was used to calculate the correlation (Pearson correlation) coefficient. The significant variations within treatments in each rice variety were analyzed by one-way ANOVA and subsequently by Duncans's multiple range tests. Two- way ANOVA was carried out to analyze whether the seasonal mean values differ within two varieties.
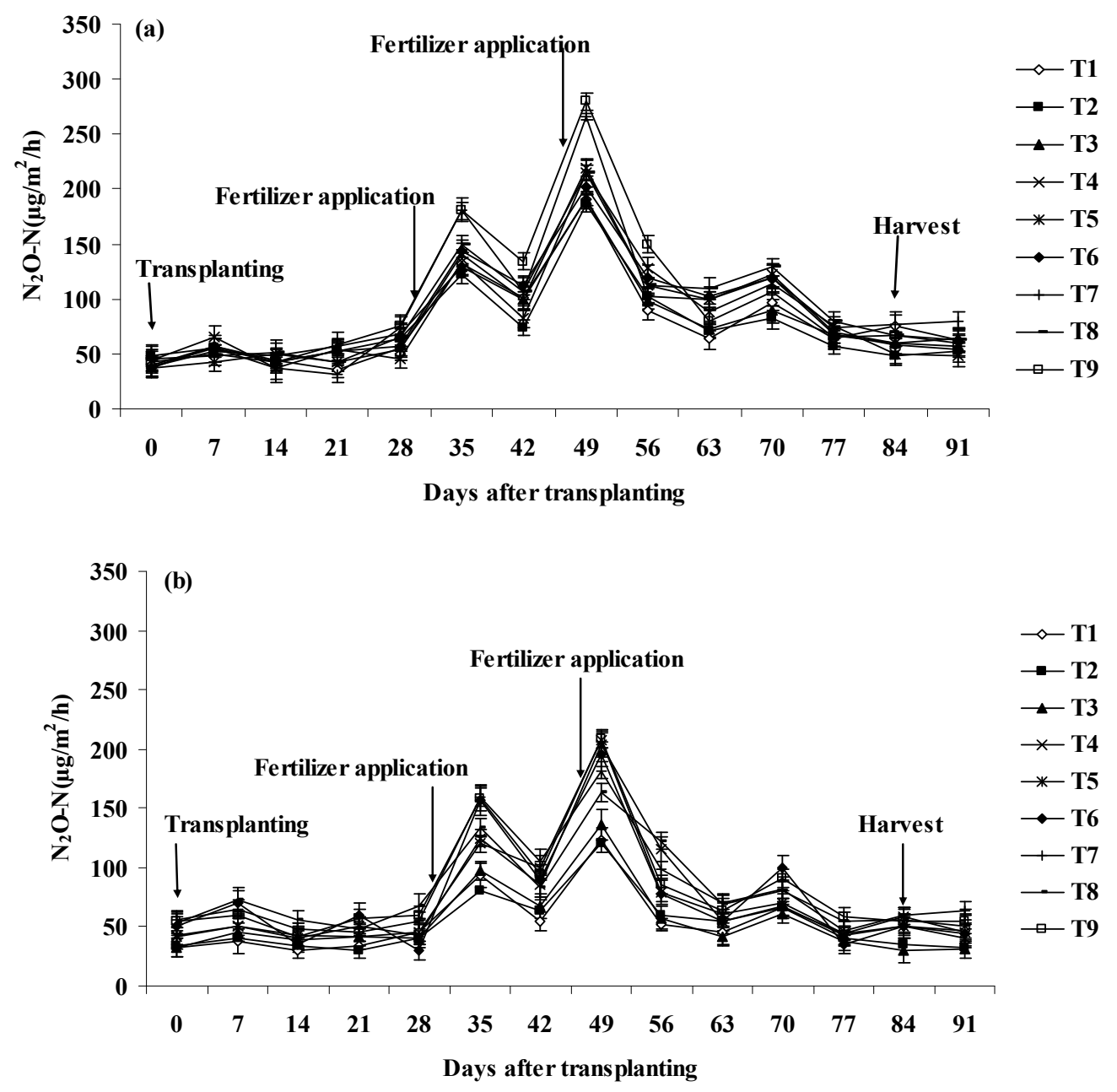

Figure 3. Nitrous oxide fluxes $\mathrm{N}_{2} \mathrm{O}-\mathrm{N}\left(\mu \mathrm{g} / \mathrm{m}^{2} / \mathrm{h}\right)$ from rice variety Phorma (a) and Luit (b) respectively, under different fertilizer treatments. Vertical bars represent standard error of three replications. The arrows indicate the time of application of fertilizers and day of harvest 
(a)
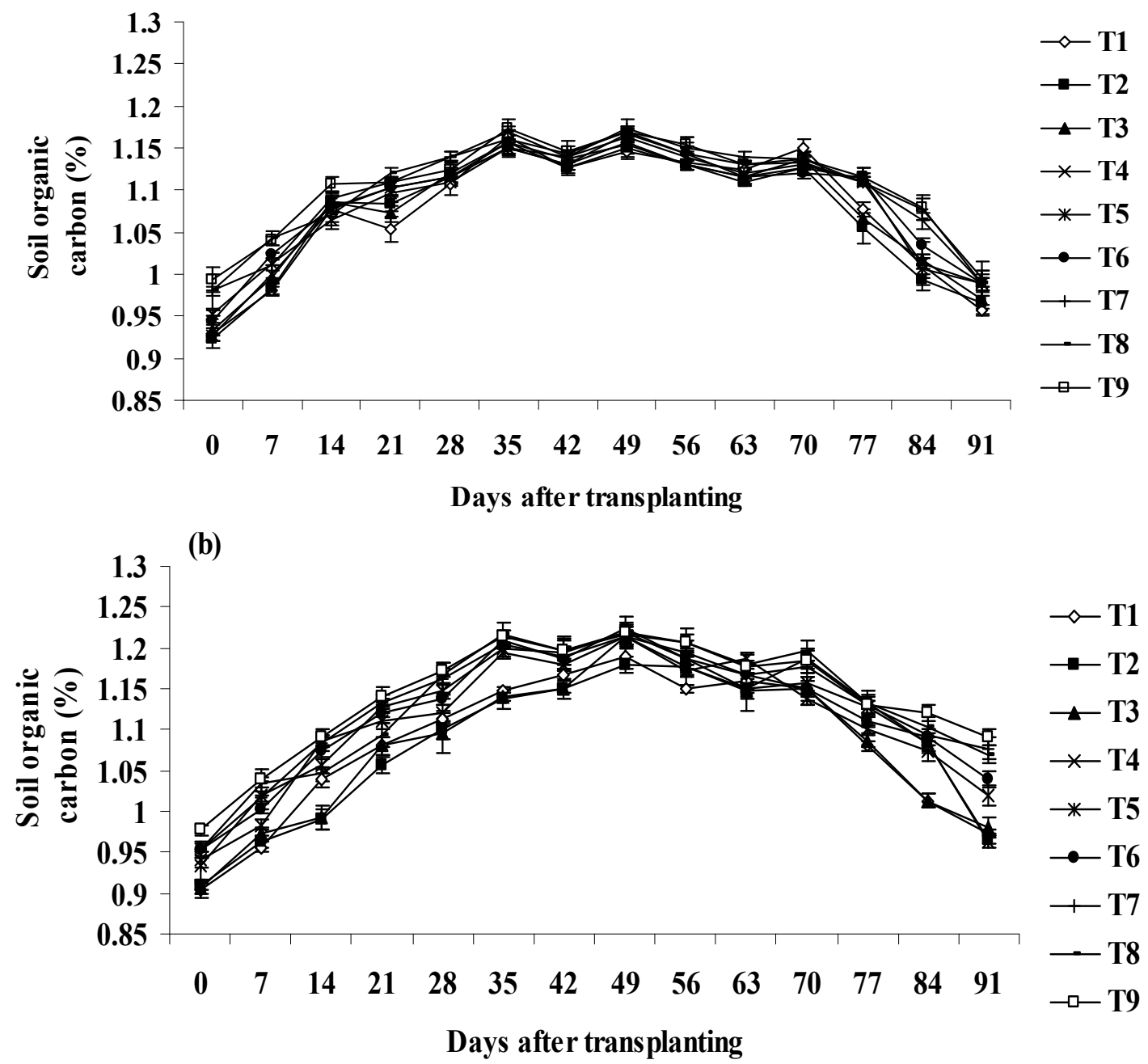

Figure 4. Soil organic carbon (\%) of the experimental field with rice variety Phorma (a) and Luit (b) respectively, under different fertilizer treatments. Vertical bars represent standard error of three replications

(a)

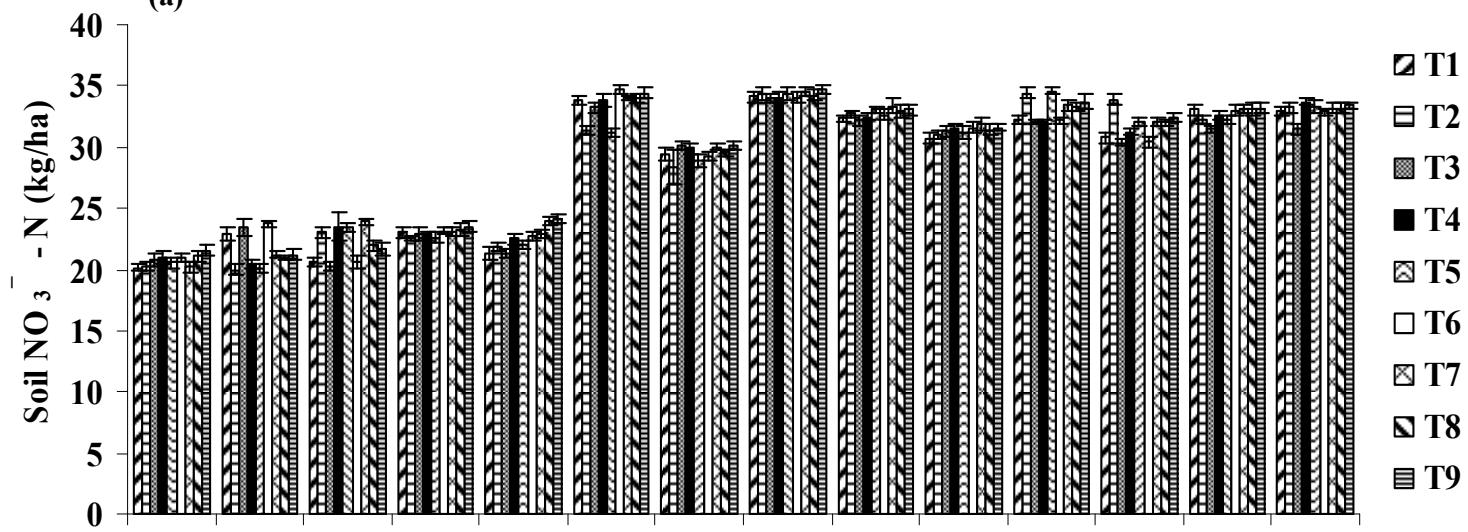

$\begin{array}{llllllllllllll}0 & 7 & 14 & 21 & 28 & 35 & 42 & 49 & 56 & 63 & 70 & 77 & 84 & 91\end{array}$

Days after transplanting 


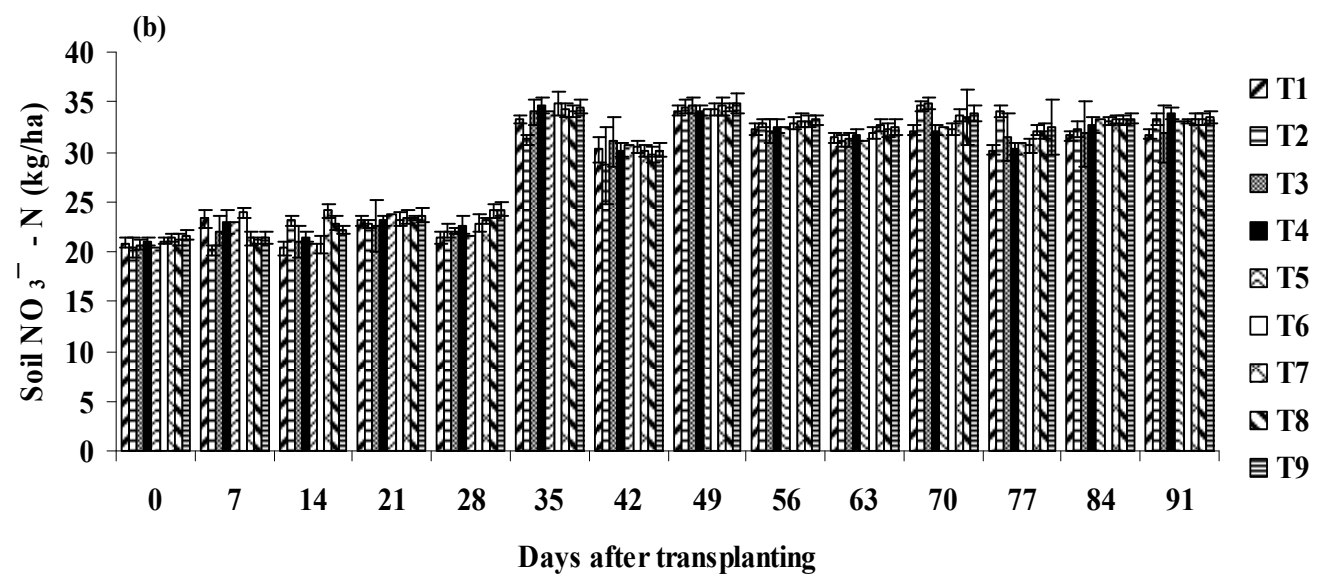

Figure 5. Soil $\mathrm{NO}_{3}{ }^{-}-\mathrm{N}(\mathrm{kg} / \mathrm{ha}$ ) of the experimental field with rice variety Phorma (a) and Luit (b) respectively, under different fertilizer treatments. Vertical bars represent standard error of three replications

\section{Results}

Mean $\mathrm{N}_{2} \mathrm{O}$ flux of 41 and $44 \mu \mathrm{g} \mathrm{N}_{2} \mathrm{O}-\mathrm{N} / \mathrm{m}^{2} / \mathrm{h}$ was observed in varieties Phorma and Luit, respectively at the time of transplanting (Figure 3). After fertilizer application at 30 DAT (days after transplanting) the mean $\mathrm{N}_{2} \mathrm{O}$ fluxes increased to $146 \mu \mathrm{g} \mathrm{N} \mathrm{N}_{2} \mathrm{O}-\mathrm{N} / \mathrm{m}^{2} / \mathrm{h}$ in Phorma and $125 \mu \mathrm{g} \mathrm{N} \mathrm{N}_{2} \mathrm{O}-$ $\mathrm{N} / \mathrm{m}^{2} / \mathrm{h}$ in Luit at 35 DAT. Again at 49 DAT elevated $\mathrm{N}_{2} \mathrm{O}$ fluxes were observed in both the varieties after fertilizer application at 47 DAT. Maximum flux values of $280 \mu \mathrm{g} \mathrm{N} \mathrm{N}_{2} \mathrm{O}$ $\mathrm{N} / \mathrm{m}^{2} / \mathrm{h}$ and $209 \mu \mathrm{g} \mathrm{N} \mathrm{N}_{2} \mathrm{O}-\mathrm{N} / \mathrm{m}^{2} / \mathrm{h}$ was observed in $\mathrm{T}_{9}\left(\mathrm{~N}, \mathrm{P}_{2} \mathrm{O}_{5}\right.$, $\mathrm{K}_{2} \mathrm{O} @$ @ 45:22:22 kg/ha as Urea, SSP, MOP + FYM) at 49 DAT in variety Phorma and Luit, respectively. Further, at 70 DAT mean $\mathrm{N}_{2} \mathrm{O}$ fluxes increased up to $109 \mu \mathrm{g} \mathrm{N} \mathrm{N}_{2} \mathrm{O}-\mathrm{N} / \mathrm{m}^{2} / \mathrm{h}$ in Phorma and $70 \mu \mathrm{g} \mathrm{N} \mathrm{N}_{2} \mathrm{O}-\mathrm{N} / \mathrm{m}^{2} / \mathrm{h}$ in Luit, respectively. We observed higher seasonal $\mathrm{N}_{2} \mathrm{O}$ emissions (Table 2) when $\mathrm{N}$, $\mathrm{P}_{2} \mathrm{O}_{5}, \mathrm{~K}_{2} \mathrm{O}$ at the rate of 45:22:22 $\mathrm{kg} / \mathrm{ha}\left(\mathrm{T}_{9}\right)$ in the form of Urea, SSP, MOP + FYM (farm yard manure) was applied followed by $\mathrm{T}_{7}\left(\mathrm{~N}, \mathrm{P}_{2} \mathrm{O}_{5}, \mathrm{~K}_{2} \mathrm{O} @\right.$ @ 40:20:20 kg/ha as Urea, SSP, $\mathrm{MOP}+\mathrm{FYM})$ and $\mathrm{T}_{8}\left(\mathrm{~N}, \mathrm{P}_{2} \mathrm{O}_{5}, \mathrm{~K}_{2} \mathrm{O} @ 35: 18: 18 \mathrm{~kg} / \mathrm{ha}\right.$ as Urea, SSP, MOP + FYM). Whereas, lowest emission was recorded when rice varieties were grown in $\mathrm{T}_{2}\left(\mathrm{~N}, \mathrm{P}_{2} \mathrm{O}_{5}, \mathrm{~K}_{2} \mathrm{O}\right.$ (a) 35:18:18 kg/ha as Urea, SSP, MOP). Variety Phorma showed higher seasonal emissions compared to Luit (Table 2). The mean seasonal $\mathrm{N}_{2} \mathrm{O}$ emissions differed significantly within two varieties $(P<0.0001)$.

Figure 4 represents the soil organic carbon (SOC) of the experimental field with rice varieties subjected to various fertilizer treatments. Significant positive correlations between SOC and $\mathrm{N}_{2} \mathrm{O}$ emission is observed in present investigation (Table 1). SOC of the treated plots were initially low and increased during maximum tillering, panicle initiation and crop ripening stage. Observed SOC is significantly higher in treatments $\mathrm{T}_{7}, \mathrm{~T}_{8}$ and $\mathrm{T}_{9}$ in both the varieties $(P<0.05)$. Seasonal mean SOC differ significantly within varieties $(P<0.0001)$. The soil $\mathrm{NO}_{3}^{-}-\mathrm{N}$ content showed significant positive correlation with $\mathrm{N}_{2} \mathrm{O}$ emission (Table 1). Soil $\mathrm{NO}_{3}{ }^{-}-$ $\mathrm{N}$ of the experimental field with the variety Phorma and Luit grown at different level of fertilizer treatments are shown in
Figure 5. Soil $\mathrm{NO}_{3}^{-}-\mathrm{N}$ content was initially low and increased rapidly from 35 DAT onwards till crop ripening. High soil $\mathrm{NO}_{3}{ }^{-}$content was recorded in treatment $\mathrm{T}_{9}$ followed by $T_{7}$ and $T_{8}$ in both the varieties. Seasonal mean soil $\mathrm{NO}_{3}^{-}$content varied significantly within varieties $(P<0.0001)$.

Rice varieties at different levels of fertilizers recorded maximum yield in $\mathrm{T}_{7}$ followed by $\mathrm{T}_{1}, \mathrm{~T}_{4}, \mathrm{~T}_{6}, \mathrm{~T}_{3}, \mathrm{~T}_{9}, \mathrm{~T}_{8}, \mathrm{~T}_{5}$ and $T_{2}$ (Table 2). Compared to Phorma variety Luit had higher yield potential. Variety Luit also recorded higher thousand grain weights compared to Phorma. Higher grain sterility (\%) was observed in treatment $\mathrm{T}_{2}$ followed by $\mathrm{T}_{5}, \mathrm{~T}_{8}$, $T_{9}, T_{3}, T_{6}, T_{4}, T_{1}$ and $T_{7}$ in both the varieties. variations in length of panicle within the treatments were not significant. Phorma recorded more number of panicle/unit area (square meter land area).

\section{Discussion}

The observed $\mathrm{N}_{2} \mathrm{O}$ emission peaks after fertilizer applications at active vegetative (35 DAT) and panicle initiation stages (49 DAT) after topdressing of nitrogenous fertilizer in the form of urea at 30 DAT and 47 DAT, are attributed to increased substrate $\left(\mathrm{NO}_{3}{ }^{-}-\mathrm{N}\right)$ which is evident from increased soil nitrate content of the experimental field at these stages (Figure 5). The emission peaks at 70 DAT in both varieties (Figure 3) is associated with high $\mathrm{N}_{2} \mathrm{O}$ production in the rice rhizosphere as a result of decomposition of leaf litters and crop roots. It is reported that incorporation of plant residues in soils increases the denitrification enzyme activity and influence the composition and diversity of the denitrifying community and thus effects $\mathrm{N}_{2} \mathrm{O}$ emissions [16]. Similar mechanism might have promoted higher $\mathrm{N}_{2} \mathrm{O}$ flux at reproductive stage (70 DAT) under the influence of different doses of fertilizer applied in rice field. Higher seasonal $\mathrm{N}_{2} \mathrm{O}$ emission in $\mathrm{T}_{9}$ is attributed to more substrate availability $\left(\mathrm{NH}_{4}^{+}\right.$and $\left.\mathrm{NO}_{3}{ }^{-}\right)$for nitrifying and denitrifying microorganisms, which is contributed by higher dose of applied $\mathrm{N}$ in the form of urea. Applied FYM along with urea might have provided additional $\mathrm{C}$ and $\mathrm{N}$ 
substrates of nitrification and denitrification in $\mathrm{T}_{9}$. Similar results of higher $\mathrm{N}_{2} \mathrm{O}$ emission after application of $\mathrm{N}$ fertilizers along with manure is reported by [17]. It was reported that emission of $\mathrm{N}_{2}$ and $\mathrm{N}_{2} \mathrm{O}$ was greater with alkaline-producing fertilizers than with acidic fertilizers [18]. In our study relatively lower seasonal $\mathrm{N}_{2} \mathrm{O}$ emission recorded at $\mathrm{T}_{6}, \mathrm{~T}_{4}$ and $\mathrm{T}_{5}$ is primarily due to lower soil alkalinity caused by $T_{6}, T_{4}$ and $T_{5}$ compared to $T_{9}, T_{7}$ and $T_{8}$ a mechanism suggested by [18]. It is reported that more alkaline-producing fertilizers may promote denitrification under waterlogged conditions, either because of an increase in the supply of oxidizable $\mathrm{C}$ or because of a direct effect on microbial activity [19]. Similar mechanisms may have resulted increased $\mathrm{N}_{2} \mathrm{O}$ emissions in $\mathrm{T}_{9}, \mathrm{~T}_{7}$ and $\mathrm{T}_{8}$ in the present investigation. Efficient use of nutrients by rice plants can be a cause for observed lower seasonal emission in treatment $\mathrm{T}_{1}$ and $\mathrm{T}_{2}[20]$. The observed significant differences in seasonal $\mathrm{N}_{2} \mathrm{O}$ emission within varieties are attributed to variations in soil $\mathrm{C}$ input by root turnover and exudates as suggested in some earlier findings [21], [22].

In present study significant positive correlations of $\mathrm{N}_{2} \mathrm{O}$ emission with soil organic carbon (SOC) of the experimental fields is due to influence of SOC on denitrifying and nitrifying microorganisms. Since, nitrification is strongly influenced by $\mathrm{CO}_{2}$, while denitrification is driven by easily oxidizable $\mathrm{C}$ sources hence; both nitrification and denitrification are supported by the availability of C [23], [24]. Increased SOC at active vegetative growth stage in our study is attributed to availability of a large quantity of decomposable organic matter and carbon from root exudates with increasing root biomass of the plants. The increased $\mathrm{N}_{2} \mathrm{O}$ emissions with increasing $\mathrm{SOC}$ at active vegetative growth stages of rice is because of increased $\mathrm{C}$ in rhizosphere contributed by increased rate of plant growth parameters like roots, leaves and tillers. Higher mean SOC observed in the field treated with $\mathrm{T}_{9}, \mathrm{~T}_{7}$ and $\mathrm{T}_{8}$ are attributed to application of farm yard manure along with fertilizer $\mathrm{N}$ (urea) which might have increased SOC and stimulated $\mathrm{N}_{2} \mathrm{O}$ emission. Our results are in agreement with earlier findings [25], [26]. It was reported that an increase in $\mathrm{N}_{2} \mathrm{O}$ emission from $3.11 \mathrm{~kg}$
$\mathrm{N} /$ ha/year to $4.43 \mathrm{~kg} \mathrm{~N} / \mathrm{ha} /$ year was because of increased soil organic carbon from $0.5 \%$ to $2 \%$, in summer maize ecosystem [25]. In a laboratory incubation experiment higher $\mathrm{N}_{2} \mathrm{O}$ emission was observed from farm yard manure treated soils [26]. It was suggested that the long-term application of farmyard manure and the associated increase in soil organic carbon and nitrogen stocks promote emissions of $\mathrm{N}_{2} \mathrm{O}$ [25], [26].

Soil $\mathrm{NO}_{3}{ }^{-}-\mathrm{N}$ and $\mathrm{N}_{2} \mathrm{O}$ emission in present investigation are found to be significantly correlated (Table 1). This is because the main substrates for nitrification and denitrification in soils are $\mathrm{NH}_{4}{ }^{+}$and $\mathrm{NO}_{3}{ }^{-}$, which may be derived from either decomposition of organic matter or the addition of fertilizers [6]. Relatively low soil $\mathrm{NO}_{3}^{-}$(Figure 5) of the fields observed in our study at initial period is due to loss of $\mathrm{NO}_{3}{ }^{-}$ through denitrification under submerged soil condition (standing water level more than $3 \mathrm{~cm}$ ). Increased soil $\mathrm{NO}_{3}{ }^{-}$ $\mathrm{N}$ at active vegetative and panicle initiation stages is contributed by fertilizer urea topdressing at these stages in rice. Higher soil $\mathrm{NO}_{3}{ }^{-}-\mathrm{N}$ at crop ripening and maturity stages were due to increased availability of mineralized soil organic nitrogen in soil as a result of decomposition of senesced older leaves and roots.

Maximum yield was recorded in $\mathrm{T}_{7}$ followed by $\mathrm{T}_{1}, \mathrm{~T}_{4}, \mathrm{~T}_{6}$, $\mathrm{T}_{3}, \mathrm{~T}_{9}, \mathrm{~T}_{8}, \mathrm{~T}_{5}$ and $\mathrm{T}_{2}$ (Table 2). Although no significant difference in yield was observed in $T_{7}$ and $T_{1}$ in both rice varieties (Table 2), the seasonal $\mathrm{N}_{2} \mathrm{O}$ emission is significantly reduced due to treatment $T_{1}$ compared to $T_{7}$. Similarly there is no significant difference in yield between the treatments $\mathrm{T}_{4}$ and $\mathrm{T}_{6}$, but seasonal $\mathrm{N}_{2} \mathrm{O}$ emission is significantly lower in $\mathrm{T}_{4}$ than $\mathrm{T}_{6}$ (Table 2). Our results are in agreement with earlier study which reported that a significant reduction in $\mathrm{N}_{2} \mathrm{O}$ emissions from the soil would be possible by reducing $\mathrm{N}$ fertilizer application in the order of $50 \%$ without critically altering grain yield or quality [5]. Similarly difference in yield in the treatments $T_{3}, T_{9}$ and $T_{8}$ are not significant but differences in seasonal $\mathrm{N}_{2} \mathrm{O}$ emission were observed which might be due to differences in fertilizer doses and combinations.

Table 1. Correlation of soil parameters with nitrous oxide emission

\begin{tabular}{|c|c|c|c|c|c|c|c|c|c|}
\hline \multirow{2}{*}{ Varieties/Parameters } & \multicolumn{9}{|c|}{ Correlation coefficient } \\
\hline & $T_{1}$ & $\mathbf{T}_{2}$ & $T_{3}$ & $\mathbf{T}_{4}$ & $T_{5}$ & $T_{6}$ & $\mathbf{T}_{7}$ & $\mathbf{T}_{8}$ & $\mathrm{~T}_{9}$ \\
\hline \multicolumn{10}{|l|}{ Phorma } \\
\hline Soil organic carbon (\%) & $\begin{array}{l}0.643 * \\
\mathrm{P}=0.033\end{array}$ & $\begin{array}{l}0.622 * \\
\mathrm{P}=0.041\end{array}$ & $\begin{array}{l}0.686^{*} \\
P=0.020\end{array}$ & $\begin{array}{l}0.665^{*} \\
\mathrm{P}=0.026\end{array}$ & $\begin{array}{l}0.669 * \\
P=0.025\end{array}$ & $\begin{array}{l}0.754 * * \\
\mathrm{P}=0.007\end{array}$ & $\begin{array}{l}0.659^{*} \\
\mathrm{P}=0.027\end{array}$ & $\begin{array}{l}0.747 * * \\
\mathrm{P}=0.008\end{array}$ & $\begin{array}{l}0.762 * * \\
P=0.006\end{array}$ \\
\hline Soil $\mathrm{NO}_{3}{ }^{-}-\mathrm{N}(\mathrm{kg} / \mathrm{ha})$ & $\begin{array}{l}0.754^{* *} \\
P=0.007\end{array}$ & $\begin{array}{l}0.603 * \\
\mathrm{P}=0.050\end{array}$ & $\begin{array}{l}0.723^{*} \\
\mathrm{P}=0.012\end{array}$ & $\begin{array}{l}0.783 * * \\
P=0.004\end{array}$ & $\begin{array}{l}0.787 * * \\
P=0.004\end{array}$ & $\begin{array}{l}0.855^{* *} \\
\mathrm{P}=0.001\end{array}$ & $\begin{array}{l}0.725^{*} \\
\mathrm{P}=0.012\end{array}$ & $\begin{array}{l}0.831^{* *} \\
\mathrm{P}=0.002\end{array}$ & $\begin{array}{l}0.706^{*} \\
\mathrm{P}=0.015\end{array}$ \\
\hline \multicolumn{10}{|l|}{ Luit } \\
\hline Soil organic carbon (\%) & $\begin{array}{l}0.618^{*} \\
P=0.043\end{array}$ & $\begin{array}{l}0.625 * \\
P=0.040\end{array}$ & $\begin{array}{l}0.631^{*} \\
\mathrm{P}=0.037\end{array}$ & $\begin{array}{l}0.648^{*} \\
P=0.031\end{array}$ & $\begin{array}{l}0.680^{*} \\
\mathrm{P}=0.021\end{array}$ & $\begin{array}{l}0.625^{*} \\
P=0.040\end{array}$ & $\begin{array}{l}0.637^{*} \\
\mathrm{P}=0.035\end{array}$ & $\begin{array}{l}0.669^{*} \\
P=0.024\end{array}$ & $\begin{array}{l}0.651^{*} \\
\mathrm{P}=0.030\end{array}$ \\
\hline Soil $\mathrm{NO}_{3}{ }^{-}-\mathrm{N}(\mathrm{kg} / \mathrm{ha})$ & $\begin{array}{l}0.709^{*} \\
\mathrm{P}=0.015\end{array}$ & $\begin{array}{l}0.644^{*} \\
\mathrm{P}=0.032\end{array}$ & $\begin{array}{l}0.607^{*} \\
\mathrm{P}=0.047\end{array}$ & $\begin{array}{l}0.665^{*} \\
P=0.026\end{array}$ & $\begin{array}{l}0.650^{*} \\
P=0.030\end{array}$ & $\begin{array}{l}0.675^{*} \\
\mathrm{P}=0.023\end{array}$ & $\begin{array}{l}0.645^{*} \\
\mathrm{P}=0.032\end{array}$ & $\begin{array}{l}0.641 * \\
P=0.034\end{array}$ & $\begin{array}{l}0.641^{*} \\
P=0.034\end{array}$ \\
\hline
\end{tabular}

* Correlation is significant at the 0.05 level of significance

** Correlation is significant at the 0.01 level of significance 
Table 2. Yield and yield attributing parameters of rice varieties and seasonal integrated nitrous oxide emission flux ( $\left.E_{\text {sif }}\right)$

\begin{tabular}{|c|c|c|c|c|c|c|c|}
\hline Rice varieties/ Parameters & $\begin{array}{l}\text { Panicle/square } \\
\text { meter }\end{array}$ & Panicle length (cm) & Sterility (\%) & $\begin{array}{l}\text { Thousand grainweight } \\
\text { (g) }\end{array}$ & Yield (q/ha) & $\begin{array}{l}\text { Esif(mg } \\
\text { N/m2) }\end{array}$ & N2O- \\
\hline \multicolumn{8}{|l|}{ Phorma } \\
\hline $\mathrm{T} 1$ & $253.00 \mathrm{ab}$ & $22.70 \mathrm{a}$ & $8.12 \mathrm{dab}$ & $19.80 \mathrm{a}$ & $26.10 \mathrm{ab}$ & $175.56 \mathrm{~h}$ & \\
\hline Т 2 & $251.67 \mathrm{ab}$ & $22.97 \mathrm{a}$ & $11.57 \mathrm{a}$ & $19.15 \mathrm{c}$ & $25.29 \mathrm{e}$ & $169.34 \mathrm{i}$ & \\
\hline Т 3 & $252.00 \mathrm{ab}$ & $22.93 a$ & $10.85 \mathrm{ab}$ & $19.84 \mathrm{a}$ & $25.77 \mathrm{abcd}$ & $179.81 \mathrm{~g}$ & \\
\hline $\mathrm{T} 4$ & $253.33 \mathrm{ab}$ & $22.37 \mathrm{a}$ & $9.76 \mathrm{c}$ & $19.95 \mathrm{a}$ & $26.07 \mathrm{ab}$ & $190.28 \mathrm{f}$ & \\
\hline T 5 & $250.00 \mathrm{~b}$ & $22.43 a$ & $11.39 \mathrm{ab}$ & $19.26 \mathrm{c}$ & $25.50 \mathrm{de}$ & $192.86 \mathrm{e}$ & \\
\hline T 6 & $252.67 \mathrm{ab}$ & $22.47 \mathrm{a}$ & $10.65 \mathrm{ab}$ & $19.80 \mathrm{a}$ & $25.97 \mathrm{abc}$ & $196.84 \mathrm{~d}$ & \\
\hline $\mathrm{T} 7$ & $254.33 \mathrm{ab}$ & $22.13 a$ & $8.06 \mathrm{~d}$ & $19.71 \mathrm{a}$ & $26.17 \mathrm{a}$ & $212.29 \mathrm{~b}$ & \\
\hline T 8 & $255.67 \mathrm{a}$ & $22.63 a$ & $11.19 \mathrm{ab}$ & $19.48 b$ & 25.57 cde & $205.46 \mathrm{c}$ & \\
\hline Т 9 & $252.33 \mathrm{ab}$ & $22.63 a$ & $11.00 \mathrm{ab}$ & $19.79 \mathrm{a}$ & $25.70 \mathrm{bcde}$ & $224.05 \mathrm{a}$ & \\
\hline \multicolumn{8}{|l|}{ Luit } \\
\hline $\mathrm{T} 1$ & $236.00 \mathrm{ab}$ & $21.77 \mathrm{a}$ & $4.63 \mathrm{~g}$ & $23.92 \mathrm{a}$ & $29.03 \mathrm{a}$ & $118.94 \mathrm{~g}$ & \\
\hline Т 2 & $232.00 \mathrm{c}$ & $20.97 \mathrm{a}$ & $7.30 \mathrm{a}$ & $23.12 b$ & $28.17 \mathrm{c}$ & $117.54 \mathrm{~g}$ & \\
\hline Т 3 & $233.67 \mathrm{abc}$ & $20.80 \mathrm{a}$ & $5.70 \mathrm{e}$ & $23.73 \mathrm{a}$ & $28.83 \mathrm{abc}$ & $121.85 \mathrm{f}$ & \\
\hline $\mathrm{T} 4$ & $235.00 \mathrm{abc}$ & $20.90 \mathrm{a}$ & $4.70 \mathrm{~g}$ & $23.74 \mathrm{a}$ & $28.97 \mathrm{ab}$ & $162.79 \mathrm{e}$ & \\
\hline Т 5 & $232.33 b c$ & $20.90 \mathrm{a}$ & $6.80 \mathrm{~b}$ & $23.18 b$ & $28.27 \mathrm{bc}$ & $161.61 \mathrm{e}$ & \\
\hline T 6 & $234.33 \mathrm{abc}$ & $21.43 \mathrm{a}$ & $5.00 \mathrm{f}$ & $23.87 \mathrm{a}$ & $28.93 \mathrm{ab}$ & $168.67 \mathrm{~d}$ & \\
\hline T 7 & $236.33 a$ & $21.57 \mathrm{a}$ & $4.54 \mathrm{~g}$ & $23.89 \mathrm{a}$ & $29.10 \mathrm{a}$ & $179.98 \mathrm{~b}$ & \\
\hline Т 8 & $232.67 \mathrm{abc}$ & $21.20 \mathrm{a}$ & $6.50 \mathrm{c}$ & $23.64 \mathrm{a}$ & $28.37 \mathrm{abc}$ & $177.74 \mathrm{c}$ & \\
\hline Т 9 & $233.00 \mathrm{abc}$ & $20.67 \mathrm{a}$ & $6.27 \mathrm{~d}$ & $23.67 \mathrm{a}$ & $28.77 \mathrm{abc}$ & $182.16 \mathrm{a}$ & \\
\hline
\end{tabular}

In each column, means with the similar letters are not significantly different at $P<0.05$ level by Duncan's multiple range test

\section{Conclusions}

Present study showed that fertilizer dose and combination significantly influences temporal and seasonal $\mathrm{N}_{2} \mathrm{O}$ emission. $\mathrm{N}_{2} \mathrm{O}$ emission estimation under the influence of different level of fertilizer application revealed that $\mathrm{T}_{1}\left(\mathrm{~N}, \mathrm{P}_{2} \mathrm{O}_{5}, \mathrm{~K}_{2} \mathrm{O}\right.$ (a) 40: 20: $20 \mathrm{~kg} / \mathrm{ha}$ as Urea, SSP, MOP without any organic amendment) with yield potential of $26.10 \mathrm{q} /$ ha (in Phorma) and $29.03 \mathrm{q} / \mathrm{ha}$ (in Luit) can be suitably used at North Bank Plain Agroclimatic Zone of Assam for sustaining productivity and as well for lower $\mathrm{N}_{2} \mathrm{O}$ emission.

\section{Acknowledgement}

We acknowledge the financial support received from the Department of Science and Technology, Govt. of India to conduct the present research work.

\section{References}

[1] IPCC, Climate Change, “ The Physical Science Basis Contribution of Working Group I to the Fourth Assessment Report of the IPCC, Cambridge University Press, NewYork," 2007.

[2] M. Abdalla, M. Jones, P. Ambus, and M. Williams, "Emissions of nitrous oxide from Irish arable soils: effects of tillage and reduced $\mathrm{N}$ input," Nutr. Cycl. Agroecosyst., vol. 86, pp. 53-65, 2010.

[3] Y. K. Soon, S. S. Mahil, R. L. Lemke, N. Z. Lupwayi, and C. A. Grant, "Effect of polymer-coated urea and tillage on the dynamics of available $\mathrm{N}$ and nitrous oxide emission from Gray Luvisols," Nutr. Cycl. Agroecosyst., vol. 90, pp. 267279, 2011

[4] M. T. Iqbal, "Effects of nitrogen and phosphorous fertilization on nitrous oxide emission and nitrogen loss in an irrigated rice field,” Malays. J. Soil Sci., 13, 105-117, 2009.

[5] R. Rafique, D. Hennessy, and G. Kiely, "Nitrous oxide emission from grazed grassland under different management systems," Ecosystems, vol. 14, pp. 563-582, 2011.

[6] C. Liu, K. Wang, and X. Zheng, "Responses of $\mathrm{N}_{2} \mathrm{O}$ and $\mathrm{CH}_{4}$ fluxes to fertilizer nitrogen addition rates in an irrigated wheat-maize cropping system in northern China," Biogeosciences, vol. 9, pp. 839-850, 2012.

[7] J. Yang, L. Gang, M. Jing, X. Hua, and Y. Kazuyuki, "Effect of controlled-release fertilizer on nitrous oxide emission from a winter wheat field," Nutr. Cycl. Agroecosyst., vol. 94, pp. 111-122, 2012.

[8] X. Gao, M. Tenuta, A. Nelson, B. Sparling, D. Tomasiewicz, R. M. Mohr, and B. Bizimungu, "Effect of nitrogen fertilizer rate on nitrous oxide emission from irrigated potato on a clay loam soil in Manitoba, Canada," Can. J. Soil Sci., vol. 93, pp. $1-11,2013$.

[9] A. K. Roy, C. Wagner-Riddle, B. Deen, J. Lauzon, and T. Bruulsema, "Nitrogen application rate, timing and history effects on nitrous oxide emissions from corn (Zea mays L.)," Can. J. Soil Sci., vol. 94, pp. 563-573, 2014.

[10] B. Gogoi, and K. K. Baruah, "Nitrous oxide emission from tea (Camellia sinensis (L.) O. kuntze)-planted soils of North East India and soil parameters associated with the emission," Cur. Sci., vol. 101, pp. 531-536, 2011.

[11] H. M. Naser, O. Nagata, S. Tamura, and R. Hatano, "Methane emissions from five paddy fields with different amounts of rice straw application in central Hokkaido Japan," Soil Sci. Plant Nutr., vol. 53, pp. 95-101, 2007.

[12] M. L. Jackson, "Soil Chemical Analysis. Prentice Hall of India Pvt. Ltd., New Delhi,” pp. 452, 1973.

[13] A. Walkley, and I. A. Black, "A critical examination of a rapid method for determining organic carbon in soil: effect of variation in digestion and inorganic soil constituents," Soil Sci., vol. 62, pp. 251-264, 1947. 
[14] A. B. Ghosh, J. C. Bajaj, R. Hasan, and D. Singh, "Soil and water testing methods," Yugantar press, IARI, New Delhi, India, pp.14-16, 1983.

[15] J. W. Nijburg, M. J. L. Coolen, S. Gerads, P. J. A. K. Gunnewiek, and H. J. Laanbroek, Effects of nitrate availability and the presence of Glyceria maxima on the composition and activity of the dissimilatory nitrate-reducing bacterial community," Applied Environ. Microbiol., vol. 63, pp. 931-93, 1997.

[16] G. L. Velthof, J. K. Peter, and O. Oene, "Nitrous oxide emission from animal manures applied to soil under controlled conditions," Biol. Fertil. Soils, vol. 37, pp. 221230, 2003 .

[17] R. L. Mulvaney, S. A. Khan, and C. S. Mulvaney, "Nitrogen fertilizers promote Denitrification," Biol. Fertil. Soils, vol. 24, pp. 211-220, 1997.

[18] S. Sen, and P. M. Chalk, "Solubilization of soil organic $\mathrm{N}$ by alkaline-hydrolysing $\mathrm{N}$ fertilizers," Fertil. Res., vol. 38, pp. 131-139, 1994.

[19] G. J. Monteny, A. Bannink, and D. Chadwick, "Greenhouse gas abatement strategies for animal husbandry," Agri. Ecosyst. Environ., vol. 112, pp. 163-170, 2006.
[20] Y. Kuzyakov, and G. Domanski, "Carbon inputs by plants into the soil," J. Plant Nutr. Soil Sci., vol. 163, pp. 421-431, 2000 .

[21] N. Millar, and E. M. Baggs, "Relationships between $\mathrm{N}_{2} \mathrm{O}$ emissions and water-soluble $\mathrm{C}$ and $\mathrm{N}$ contents of agroforestry residues after their addition to soil," Soil Biol. Biochem., vol. 37, pp. 605-608, 2005.

[22] F. Azam, S. Gill, and S. Farooq, Availability of $\mathrm{CO}_{2}$ as a factor affecting the rate of nitrification in soil," Soil Biol. Biochem., vol. 37, pp. 2141-2144, 2005.

[23] E. G. Beauchamp, J. T. Trevors, and J. W. Paul, "Carbon sources for bacterial denitrification," Adv. Soil Sci., vol. 10, pp. 113-142, 1989.

[24] Y. Wang, G. J. Sun, F. Zhang, J. Qi, Z. D. Feng, and C. Y. Zhao, "Modeling impacts of farming management practices on greenhouse gas emissions in the oasis region of China," Biogeosciences Disc., vol. 8, pp. 3121-3153, 2011.

[25] N. Jager, C. F. Stange, B. Ludwig and H. Flessa, "Emission rates of $\mathrm{N}_{2} \mathrm{O}$ and $\mathrm{CO}_{2}$ from soils with different organic matter content from three long-term fertilization experiments - a laboratory study," Biol. Fertil. Soils, vol. 47, pp. 483-494, 2011. 